\title{
71. CONSOLIDATION CHARACTERISTICS AND PERMEABILITIES OF SEDIMENTS FROM THE JAPAN SEA (SITES 798 AND 799) ${ }^{1}$
}

\author{
Peter R. Holler ${ }^{2}$
}

\begin{abstract}
The results of laboratory consolidation tests and undrained shear strength determinations of sediments from the Oki Ridge and the Kita Yamato Trough show that the sediments are overconsolidated to normally consolidated to a depth of about $20 \mathrm{~m}$ below the seafloor. Below that depth, the sediments are highly underconsolidated, implying high excess pore-water pressures. The most probable mechanism for the generation of the excess pore-water pressure is gas in sediments.
\end{abstract}

\section{INTRODUCTION}

Consolidation has been defined by Skempton (1970) as the result of all processes causing the progressive transformation of an argillaceous sediment from a soft mud to a clay and finally to a mudstone or shale. The processes involved include particle bonding, desiccation, cementation, and the squeezing out of pore water under increasing weight of overburden. The last-mentioned process is also known as gravitational compaction. Laboratory consolidation tests simulate gravitational compaction by applying an increasing vertical load upon a small, free-draining, confined, cylindrical sediment sample. The theory of consolidation has been described in detail by Terzaghi (1943), Taylor (1948), Bryant et al. (1981), and Bryant and Bennett (1988).

Previous studies on consolidation of marine sediments were summarized by Bryant and Bennett (1988). Consolidation tests of sediments from the Japan Sea were conducted by Trabant et al. (1975) for five samples recovered during DSDP Leg 31 . Two samples were from Site 299 (Fig. 1), drilled in the Yamato Basin, and three samples from Site 302 (Fig. 1), drilled on the northern flank of the Yamato Rise. The study of Trabant et al. (1975) showed that the sediments from Site 299 were generally underconsolidated as a result of the high sedimentation rate of $200 \mathrm{~m} / \mathrm{m}$.y. Site 302 samples from a depth of 27 and $141 \mathrm{mbsf}$ were normally consolidated, whereas the sample from 196 mbsf was slightly underconsolidated.

This paper addresses the following objectives:

1. To determine the state of consolidation of sediments from the Japan Sea, using shear strength-overburden pressure relationships and consolidation tests, to compare the results of the two different methods, and to compare these results with those of Leg 31;

2. To estimate pore-water pressure distribution with increasing depth.

3. To determine the permeabilities of sediments using direct measurements and computations from laboratory consolidation tests, correlation between porosity and permeability, and to understand the influence of grain-size and lithology on permeability.

\section{MATERIALS, METHODS, AND DEFINITIONS}

Twelve 10-cm-long whole-round sediment samples were collected during Leg 128 from Site 798 on the Oki Ridge and Site 799 in the Kita Yamato Trough (Fig. 1).

After shipment by air-freight to the physical properties laboratory of Kiel University, the whole-round samples were X-rayed to check the degree of sample disturbance. The methods used included stand-

\footnotetext{
'Tamaki, K., Suyehiro, K., Allan, J., McWilliams, M., et al., 1992. Proc. ODP, Sci. Results, 127/128, Pt. 2: College Station, TX (Ocean Drilling Program).

${ }^{2}$ Geologisch-Paläontologisches Institut der Universität Kiel, Olshausenstrasse 40-60, W-2300 Kiel, Federal Republic of Germany.
}

ard X-ray radiography, as described by Bouma (1969), and the computer tomographic technique, as described by Holler and Kögler (1990). A comparison of a conventional X-ray radiograph with computer tomograms highlights the much better resolution and contrast of the features on the tomograms (see Pl. 1).

Grain-size analyses were carried out by standard pipette method. Index properties were determined following the methods described by the Shipboard Scientific Party (1990a). Atterberg limit determinations (liquid limit, plastic limit, plasticity index) followed Casagrande (1932). On the whole-round samples, undrained shear strength was measured perpendicular to bedding, using a miniature vane test device (Holler, 1989).

The sedimentary overburden pressure $\left(p_{o}\right)$ was calculated for every depth interval using the equation from Richards (1962):

$$
p_{o}=\left(d_{B} \times z\right)+p_{a}(\mathrm{kPa})
$$

where

$p_{o}=$ sedimentary overburden pressure,

$d_{B}=$ buoyant unit weight (wet-bulk density minus density of water),

$z=$ depth interval,

$p_{a}=$ sedimentary overburden pressure of upper depth interval.

Consolidation tests were performed on cylindrical samples $\left(20 \mathrm{~cm}^{2}\right.$ $\times 2 \mathrm{~cm}$ ) using standard procedures, as described by Lambe (1951). The consolidation apparatuses used were of the Karol Warner Conbel type. The loads were increased with time and doubled at 24-hr intervals. The following vertical loads were used for the consolidation tests: $5.6,11,22,44,88,167,355,709,1418,2855$, and $5670 \mathrm{kPa}$.

The results of the tests are displayed as void ratio vs. the logarithm of normal pressure, called e-log p curves. The preconsolidation pressure, $p_{c}$, is the greatest load to which the sediment has ever been subjected. The preconsolidation pressure was determined from the rebound characteristics and the reload curve. as described by Bryant et al. (1986), and Bryant and Bennett (1988). The ratio between the preconsolidation pressure $\left(p_{c}\right)$ and the present overburden pressure $\left(p_{o}\right)$ is called the overconsolidation ratio (OCR).

A sediment sample is said to be normally consolidated if the present overburden pressure is equal to the preconsolidation pressure determined for that sample $(\mathrm{OCR}=1)$.

Overconsolidation exists if the preconsolidation pressure is higher than the present overburden pressure $(\mathrm{OCR}>1)$.

An underconsolidated sample $(\mathrm{OCR}<1)$ is one in which the preconsolidation pressure is smaller than the present overburden pressure. Bryant and Bennett (1988) pointed out that underconsolidated sediments generally exhibit excess pore water pressure (pressure in excess of hydrostatic) and are not yet completely consolidated.

Permeability is defined by Matthews and Boyer (1976) as the capacity of rocks for transmitting a fluid. Permeability can be meas- 


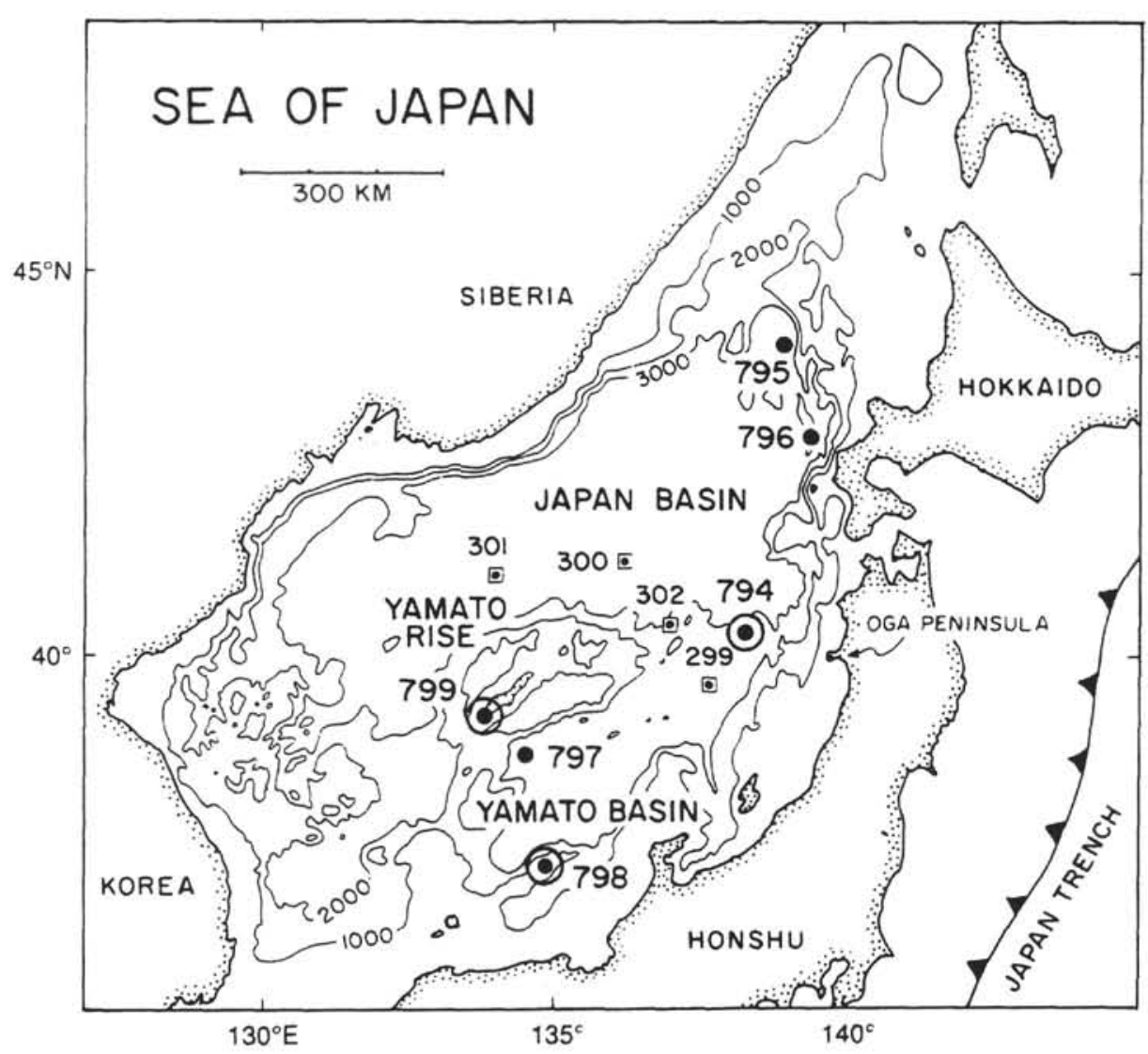

Figure 1. Location of Legs 31 (boxed dots), 127 (dots), and 128 (circled dots) sites in the Japan Sea.

ured directly in the laboratory using different kinds of permeameters (see The Marine Geotechnical Consortium, 1985) or calculated from the results of laboratory consolidation tests. In this study, permeability of the samples was determined directly, by using a falling-head permeameter before consolidation tests were conducted, and indirectly from the results of the consolidation tests. The indirect measure of permeability was based on the square root of time method used to determine the time required for $90 \%$ primary consolidation $\left(\mathrm{t}_{90}\right)$. Permeability was calculated after Terzaghi (1943) by means of the following equation (see also Bryant et al., 1981, 1986):

$$
k=c_{v} m_{v} d_{w},
$$

where

$k=$ coefficient of permeability $(\mathrm{cm} / \mathrm{s})$,

$c_{v}=$ coefficient of consolidation $\left(=0.848 \mathrm{H}^{2} / t_{90}\right)$,

$m_{y}=$ coefficient of volume change $\left(=(\operatorname{de} / d p) /(1+e)=a_{v} /(1+e)\right)$,

$a_{v}=$ coefficient of compressibility $(=d e / d p)$,

$e=$ void ratio,

$p=$ pressure $(\mathrm{kPa})$,

$H=$ average drainage height of sample $(\mathrm{cm})$,

$t_{90}=$ time required for $90 \%$ completion of primary consolidation, and $d_{w}=$ unit weight of pore water (taken as $1.025 \mathrm{~g} / \mathrm{cm}^{3}$ ).

\section{RESULTS AND DISCUSSION}

\section{Consolidation Characteristics Inferred From Sediment Shear Strength}

Bryant et al. (1986) stated that the most direct and definitive way of determining the degree of consolidation for normally and underconsolidated sediment conditions is to measure the in-situ pore water pressures. However, in-situ pore water pressure measurements have been conducted only in very rare cases (see Dunlap et al., 1978, 1979; Schultheiss and McPhail, 1986).

An approximation of the consolidation characteristics can be made by using the classical $c_{u} / p_{o}$-relationship (Skempton, 1970, Bryant et al., 1986). Skempton (1970) developed a method for predicting the shear strength-overburden pressure ratio for normally consolidated marine sediments, based on empirical relationships. The equation for the predicting the $c_{u} / p_{o}$-ratio is as follows:

$$
\begin{aligned}
c_{u} / p_{o} & =0.11+0.0037 \mathrm{Ip}, \\
\text { where } & \\
c_{u} & =\text { undrained shear strength, } \\
p_{o} & =\text { sedimentary overburden pressure, and } \\
I p & =\text { plasticity index. }
\end{aligned}
$$

Figures 2 and 3 show the ratios of shear strength to the sedimentary overburden pressure plotted against depth below seafloor for the upper part of Sites 798 and 799. As pointed out by the Shipboard Scientific Party (1990a), shear strength measurements were restricted to the sediments recovered by means of the advanced piston corer (APC) because sediments recovered using the extended core barrel $(\mathrm{XCB})$ and the rotary core barrel $(\mathrm{RCB})$ generally display a much higher degree of drilling disturbance.

The plots show a vertical line having a value of 0.22 . This line represents, according to Skempton (1970), the boundary between normally consolidated sediments, characterized by a $c_{u} / p_{o}$-ratio $>$ 0.22 , and underconsolidated sediments with $c_{u} / p_{o}$-ratios generally smaller than 0.22 .

The boundary between normally consolidated and overconsolidated sediments is not included on the plots. Table 1 shows the Atterberg limits and the $c_{i} / p_{o}$-ratios for normally consolidated sediments. The minimum and maximum values are 0.26 and 0.59 . All samples showing a higher $c_{u} / p_{o}$-ratio as 0.59 are defined as overconsolidated. 


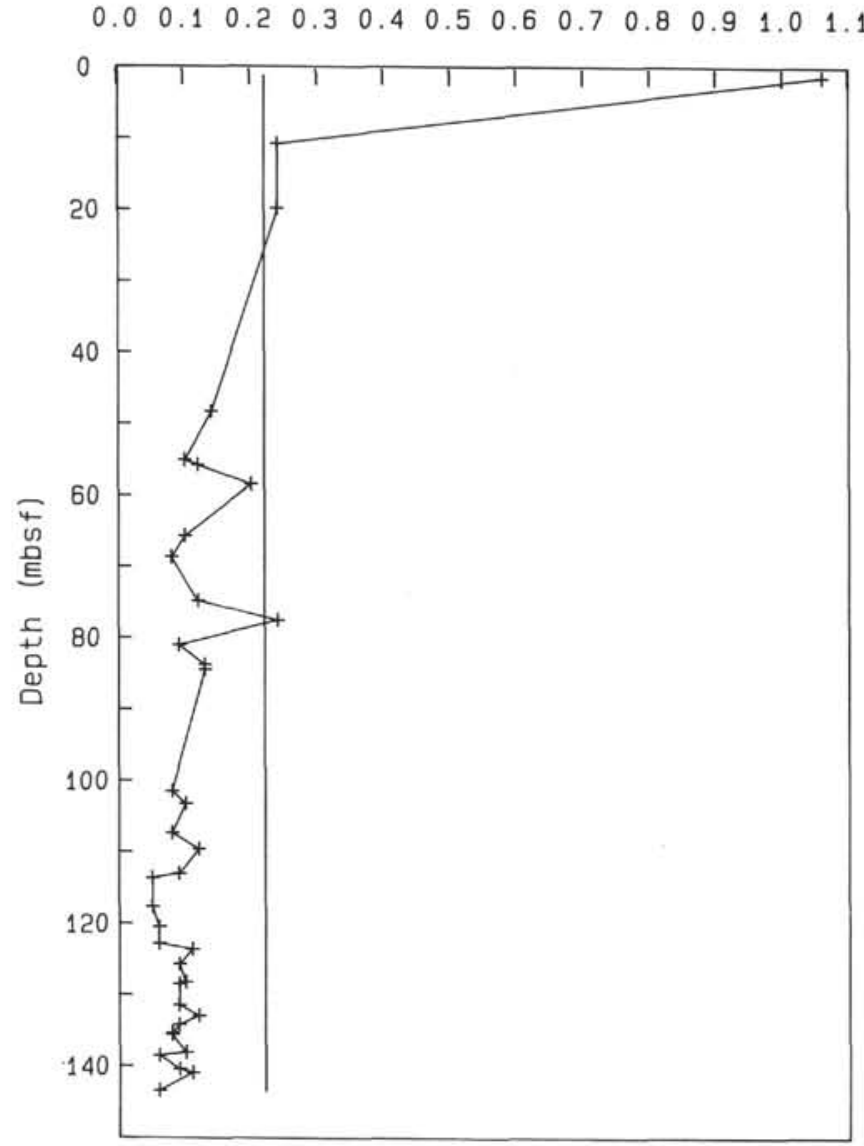

Figure 2. Undrained shear strength/sedimentary overburden pressure ratios for Site 798. Sediments having ratios less than 0.22 are underconsolidated.

\section{Site 798}

Figure 2 shows the $c_{u} / p_{o}$-ratio vs. depth for Site 798. Samples from the upper $20 \mathrm{mbsf}$ display $c_{u} / p_{o}$-ratios that range between 1.06 and 0.24 . As mentioned above, these values represent overconsolidated to normally consolidated conditions of the samples.

Below $20 \mathrm{mbsf}$, the $c_{d} / p_{o}$-ratio is, except for the depth interval of about $78 \mathrm{mbsf}$, generally smaller than 0.22 and shows a decrease with increasing depth. This indicates that all sediments below $20 \mathrm{mbsf}$ are underconsolidated (except the sample at the depth of about $78 \mathrm{mbsf}$, which is normally consolidated) and that the state of underconsolidation increases with increasing depth below seafloor.

\section{Site 799}

The consolidation state of Site 799 as inferred from shear strength determination is shown in Figure 3 . The highest $c_{u} / p_{o}$-ratio was determined near the top of Core 128-799A-1H-1. Below Section 1 of this core, the $c_{u} / p_{o}$-ratio shows values generally smaller than 0.22 . The upper 180 mbsf of Site 799 are interpreted to be generally underconsolidated and that only the uppermost part of this site is overconsolidated. A decreasing $c_{u} / p_{o}$-ratio was determined with increasing depth below seafloor at this site. This decrease represents an increasing state of underconsolidation with increasing depth.

The depth interval between about 40 and $60 \mathrm{mbsf}$ is characterized by mass movement deposits like debris flow deposits and folded

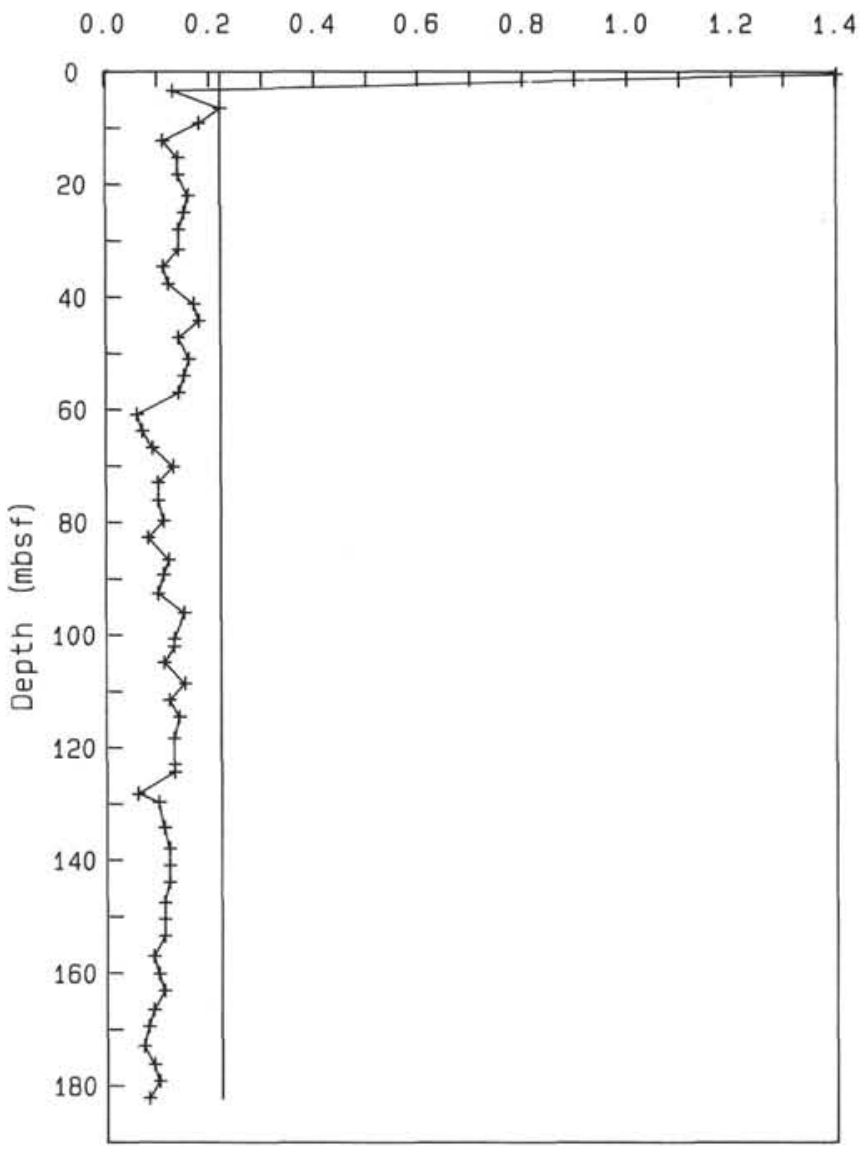

Figure 3. Undrained shear strength/sedimentary overburden pressure ratios for Site 799. Sediments having ratios less than 0.22 are underconsolidated.

sediment sections (see "Lithostratigraphy" section in Shipboard Scientific Party, 1990c). It is interesting to note that the $c_{t} / p_{o}$ ratios in that depth interval are generally higher, compared to the depth intervals above and below it (Fig. 3). An explanation for the higher values of the $c_{u} / p_{o}$-ratio is a more dense packing of the sediments, due to the mass movement. A generally higher degree of consolidation within debris flow deposits from various parts of the world (e.g., the North Fiji Basin, off northwest Africa, in the Equatorial East Atlantic, and off Norway) has been demonstrated by Holler (1988).

Figure 3 also shows that the sediment directly below the mass movement deposits are highly underconsolidated. This high degree of underconsolidation can be explained by the rapid loading of the sediments due to the mass movement deposits.

Another "slump" deposit was detected in the depth interval between 145 and 155 mbsf (see Shipboard Scientific Party, 1990c). The $c_{u} / p_{o}$-ratio at a depth of $157 \mathrm{mbsf}$ also indicates a rapid loading of that depth interval by the slumped sediments.

\section{Consolidation Characteristics From Laboratory Consolidation (Oedometer) Tests}

The results of laboratory consolidation tests from Site 798 are displayed as void ratio vs. logarithm of vertical effective pressure $(e-\log p)$ diagrams in Figure 4. Table 2 is a list of the calculated overburden pressure, minimum and maximum preconsolidation pressures, overconsolidation ratio (OCR), and excess pore-water pressures for seven samples from Site 798 . 
Table 1. Atterberg limits and $c_{u} / p_{o}$-ratios for normally consolidated sediments for whole-round samples from Sites 798 and 799.

\begin{tabular}{|c|c|c|c|c|c|}
\hline $\begin{array}{l}\text { Core, section } \\
\text { interval }(\mathrm{cm})\end{array}$ & $\begin{array}{l}\text { Depth } \\
\text { (mbsf) }\end{array}$ & $\begin{array}{l}\text { Liquid } \\
\text { limit } \\
(\%)\end{array}$ & $\begin{array}{l}\text { Plastic } \\
\text { limit } \\
(\%)\end{array}$ & $\begin{array}{l}\text { Plasticity } \\
\text { index }\end{array}$ & $\begin{array}{l}c_{u} / p_{o} \\
\text { ratio }\end{array}$ \\
\hline \multicolumn{6}{|l|}{ Hole 798B } \\
\hline $1 \mathrm{H}-1,135-150$ & 1.35 & 193 & 63 & 130 & 0.59 \\
\hline $2 \mathrm{H}-1,140-150$ & 10.80 & 138 & 43 & 95 & 0.46 \\
\hline $3 \mathrm{H}-1,140-150$ & 19.80 & 123 & 40 & 83 & 0.42 \\
\hline $4 \mathrm{H}-7,84-94$ & 37.94 & 119 & 44 & 75 & 0.39 \\
\hline $9 \mathrm{H}-3,140-150$ & 78.74 & 75 & 35 & 40 & 0.26 \\
\hline $16 \mathrm{X}-6,140-150$ & 150.68 & 137 & 80 & 57 & 0.32 \\
\hline $25 X-3,140-150$ & 234.10 & 112 & 52 & 60 & 0.33 \\
\hline \multicolumn{6}{|l|}{ Hole 799A } \\
\hline $2 \mathrm{H}-1,135-145$ & 2.55 & 81 & 30 & 51 & 0.30 \\
\hline $3 \mathrm{H}-4,140-150$ & 16.60 & 77 & 28 & 49 & 0.29 \\
\hline $5 \mathrm{H}-4,135-145$ & 35.75 & 103 & 38 & 65 & 0.35 \\
\hline $10 \mathrm{H}-4,135-145$ & 83.75 & 113 & 44 & 69 & 0.37 \\
\hline $21 X-4,130-140$ & 189.90 & 143 & 68 & 75 & 0.39 \\
\hline
\end{tabular}

Sample $128-798 \mathrm{~B}-1 \mathrm{H}-1,135-150 \mathrm{~cm}$, is characterized by an average OCR of 6.17 , indicating overconsolidation. For Sample $128-798 \mathrm{~B}-2 \mathrm{H}-1,140-150 \mathrm{~cm}$, the minimum and maximum values of the OCR vary between 0.80 and 0.92 , respectively. The sediment is classified as normally consolidated to slightly underconsolidated.The remaining samples from Site 798 show OCR's ranging between 0.78 and 0.15 . The sediments are mostly underconsolidated. With increasing depth below seafloor the OCR's generally decrease (Table 2). This means that the degree of underconsolidation is greater with increasing depth below seafloor. Estimates of the state of consolidation from the laboratory consolidation tests of the sediments from Site 798 agree well with those inferred from the undrained shear strength/sedimentary overburden pressure ratio.

Figure 5 shows a plot of the sedimentary overburden pressure and the minimum and maximum preconsolidation pressure vs. depth for Site 798. As pointed out by Bryant et al. (1986), it is reasonable to assume that the difference between the preconsolidation pressure and the sedimentary overburden pressure is the approximate amount of pressure in excess of hydrostatic that one might expect in the underconsolidated sediments. Making this assumption, Figure 5 and Table

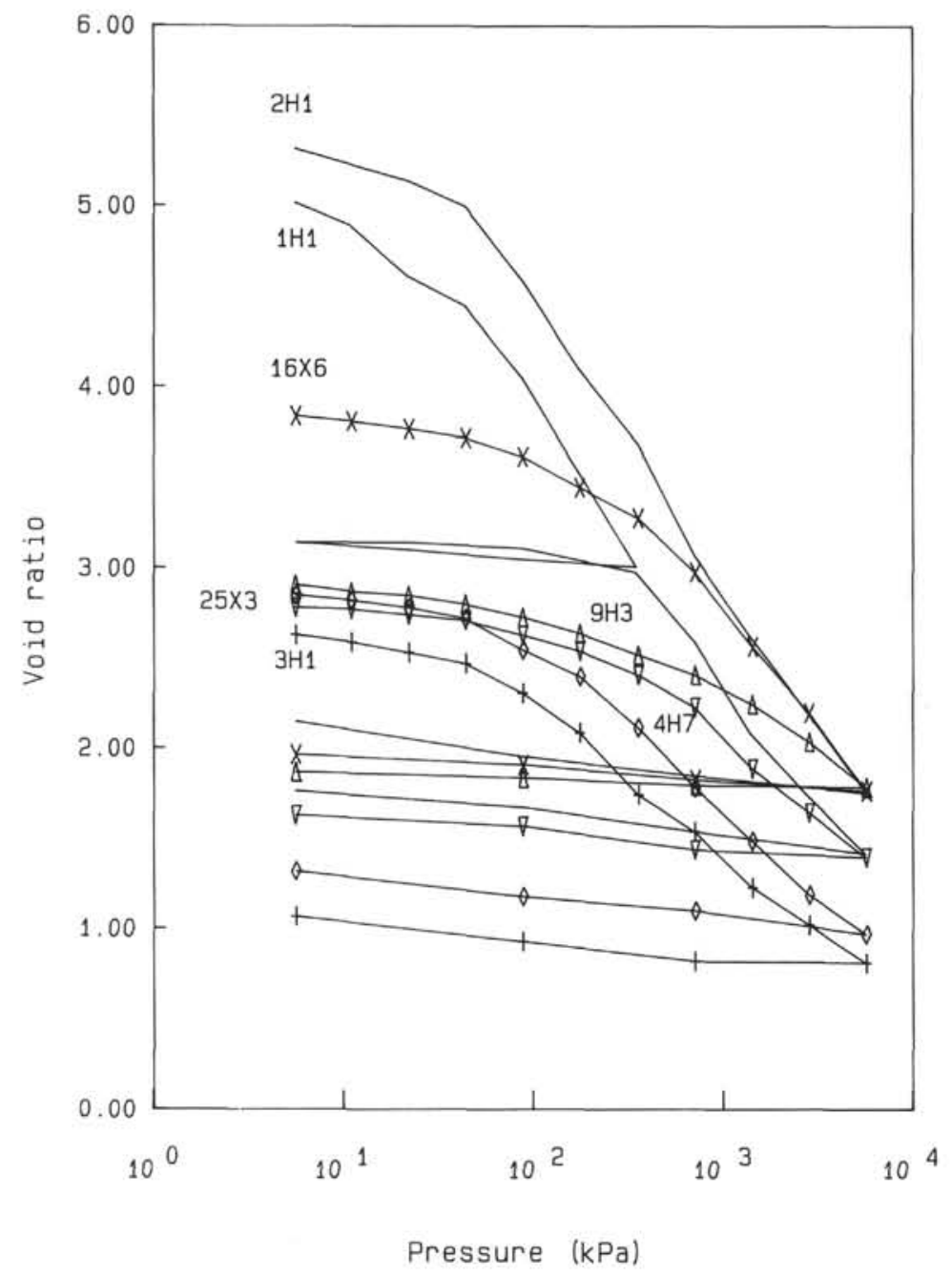

Figure 4. Void ratio vs. logarithm of vertical effective pressure plots of sediments from Site 798. 
Table 2. Consolidation characteristics and excess pore-water pressures for Site 798.

\begin{tabular}{|c|c|c|c|c|c|c|c|}
\hline \multirow{2}{*}{$\begin{array}{l}\text { Core, section. } \\
\text { interval }(\mathrm{cm})\end{array}$} & \multirow{2}{*}{$\begin{array}{l}\text { Overburden } \\
\text { pressure } \\
\text { (kPa) }\end{array}$} & \multicolumn{2}{|c|}{$\begin{array}{l}\text { Preconsolidation } \\
\text { pressure } \\
(\mathrm{kPa})\end{array}$} & \multicolumn{2}{|c|}{$\begin{array}{c}\text { Excess pore-water } \\
\text { pressure } \\
(\mathrm{kPa})\end{array}$} & \multicolumn{2}{|c|}{ OCR } \\
\hline & & $\min$. & $\max$. & $\min$. & $\max$. & $\min$. & $\max$. \\
\hline \multicolumn{8}{|l|}{ Hole 798B } \\
\hline $1 \mathrm{H}-1,1,35-150$ & 3.81 & 20.7 & 26.3 & 0.0 & 0.0 & 5.4 & 6.2 \\
\hline $2 \mathrm{H}-1.140-150$ & 45.60 & 36.3 & 41.7 & 3.8 & 9.2 & 0.8 & 0.9 \\
\hline $3 \mathrm{H}-1.140-150$ & 90.60 & 53.0 & 71.0 & 19.6 & 37.6 & 0.6 & 0.8 \\
\hline$+\mathrm{H}-7,84-94$ & 181.80 & 57.6 & 69.2 & 112.6 & 114.2 & 0.3 & 0.4 \\
\hline $9 \mathrm{H}-3,1+10-1.50$ & 404.80 & 100.0 & 170.0 & 243.8 & 304.8 & 0.2 & 0.4 \\
\hline $16 X-6.140-150$ & 774.40 & 158.5 & 213.8 & 560.6 & 615.9 & 0.2 & 0.3 \\
\hline $25 X-3,140-150$ & 1158.60 & 177.8 & 275.4 & 883.2 & 980.9 & 0.1 & 0.2 \\
\hline
\end{tabular}

2 clearly show that excess-pore water pressure generally increases with increasing depth below seafloor.

The results of the laboratory consolidation tests for the five samples from Site 799 are displayed in Figure 6 as $e-\log p$ diagrams and listed in Table 3. For Sample 128-799A-2H-1, 135-145 cm, an average overconsolidation ratio (OCR) of 1.90 was determined (Table 3), whereas the remaining samples show OCR's ranging from 0.18 to 0.89 (Table 3). Overconsolidation ratios for Site 799 generally decrease with increasing depth of burial. This indicates a greater degree of underconsolidation with increasing depth.

Figure 7 shows a plot of the sedimentary overburden pressure and the minimum and maximum preconsolidation pressures vs. depth. Figure 7 clearly shows that the excess pore-water pressure generally increases with increasing depth below seafloor.

A comparison of the consolidation characteristics from the laboratory tests with those inferred from the $c_{u} / p_{o}$-ratio vs. depth generally show excellent agreement. The sediments near the seafloor are overconsolidated, while the samples from the deeper sediments of Site 799 are generally underconsolidated. The degree of underconsolidation increases with increasing depth of burial at both sites.

\section{Permeability}

Table 4 displays the permeability (coefficient of permeability, $k$ ) determined by the falling-head technique and indirect measurements from consolidation tests. The first two columns are those permeabilities from the direct determination and the calculated permeability for the vertical effective pressure of $5.6 \mathrm{kPa}$. The third column displays the calculated permeabilities at the present estimated sedimentary overburden pressure level (assuming hydrostatic pore-pressure conditions), which is after Bryant et al. (1986) assumed to approximate the in-situ permeability at the level in the core from where the sample was recovered. Note that the results of the direct measurements do not show values one-half to one order of magnitude higher than the calculated permeabilities from the consolidation test at the $0-5.6 \mathrm{kPa}$ level, as stated by the Marine Geotechnical Consortium (1985). However, the ratio between the direct permeability and the indirect permeability at the $0-5.6 \mathrm{kPa}$ level ranges between 0.10 and 34 , with most values between 0.7 and 1.6. One reason for this difference may be the different size of the samples used to determine direct and indirect permeabilities. For the falling-head permeameter, the height of the samples was approximately $5 \mathrm{~cm}$, whereas only 2 -cm-high samples were used for the compression tests. Although the 2-cm-high samples were taken from the 5-cm high samples after measuring direct permeability, differences in sediment texture can greatly affect these measurements. Sample 128-798B-9H-3, 140-150 cm, was composed of clayey-silty sediment, with a coarser-grained layer within the fine-grained sediment. The permeability determined for the $5-\mathrm{cm}$ long sample was $5.85 \times 10^{-6} \mathrm{~cm} / \mathrm{s}$, the permeability of the 2-cm-long sample, $1.97 \times 10^{-5} \mathrm{~cm} / \mathrm{s}$. An inspection of the $2-\mathrm{cm}$ sample after the compression test revealed that a much higher amount of coarse material was in the 2-cm sample. This observation generally confirms the findings
Pressure (kPa)

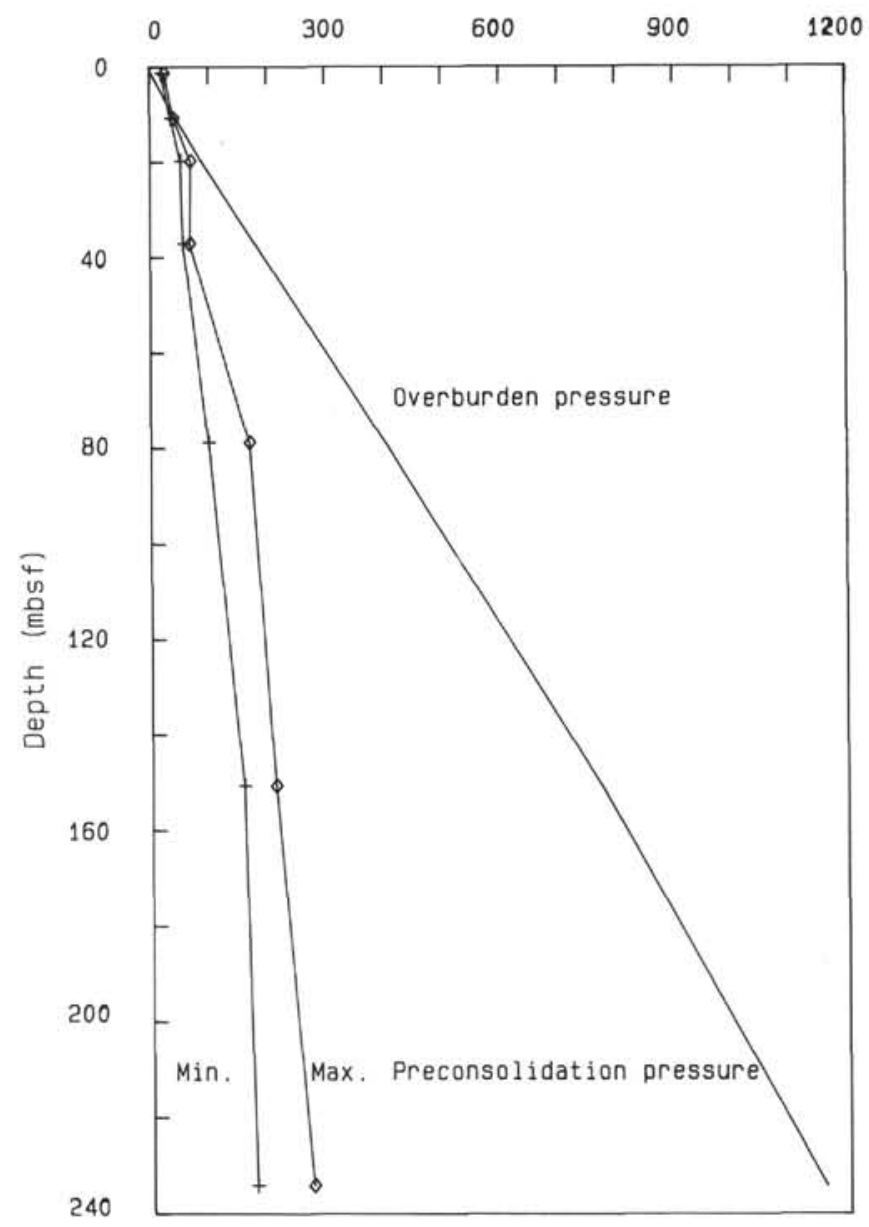

Figure 5. Plot of sedimentary overburden pressure assuming hydrostatic conditions as a function of sub-bottom depth at Site 798. The minimum and maximum preconsolidation pressure as determined from laboratory consolidation tests at Site 798 are also included. This plot shows that the excess pore-water pressure increases with increasing depth below the seafloor.

of Bryant et al. (1981) that grain size is the most important single sediment characteristic relative to its permeability. Therefore, one must determine the grain-size distribution of the samples used for permeability.

In the following section, only the permeabilities determined indirectly from consolidation tests are discussed, because only these samples allow a direct comparison between the values determined at the $0-5.6 \mathrm{kPa}$ level and those determined at the level of the present sedimentary overburden pressure.

Figure 8 shows the permeabilities at the sedimentary overburden pressure (assumed hydrostatic equilibrium) of Site 798 vs. depth below seafloor. With increasing depth, the permeability at the sedimentary overburden pressure rapidly decreases from a value of 4.30 $\times 10^{-6} \mathrm{~cm} / \mathrm{s}$ at a depth of $1.34 \mathrm{mbsf}$ to $4.22 \times 10^{-8} \mathrm{~cm} / \mathrm{s}$ at a sub-bottom depth of $10.80 \mathrm{~m}$. Permeability decreases to a value of $3.45 \times 10^{-8}$ $\mathrm{cm} / \mathrm{s}$ at a depth of about 37 mbsf. Sample 128-798B-9H-3, 140-150 $\mathrm{cm}$, is characterized by an increased permeability of $3.72 \times 10^{-8} \mathrm{~cm} / \mathrm{s}$. The permeabilities of Samples 128-798B-16X-6, 140-150 cm, and 128-798B-25X-3, 140-150 cm, increase to values of $5.50 \times 10^{-8} \mathrm{~cm} / \mathrm{s}$ and $5.35 \times 10^{-8} \mathrm{~cm} / \mathrm{s}$, respectively (Table 4). This increase of permeability with increasing depth below seafloor cannot be explained by a changing texture of the sediments. Table 5 displays the results of grain-size determinations for Sites 798 and 799. As can be seen from 


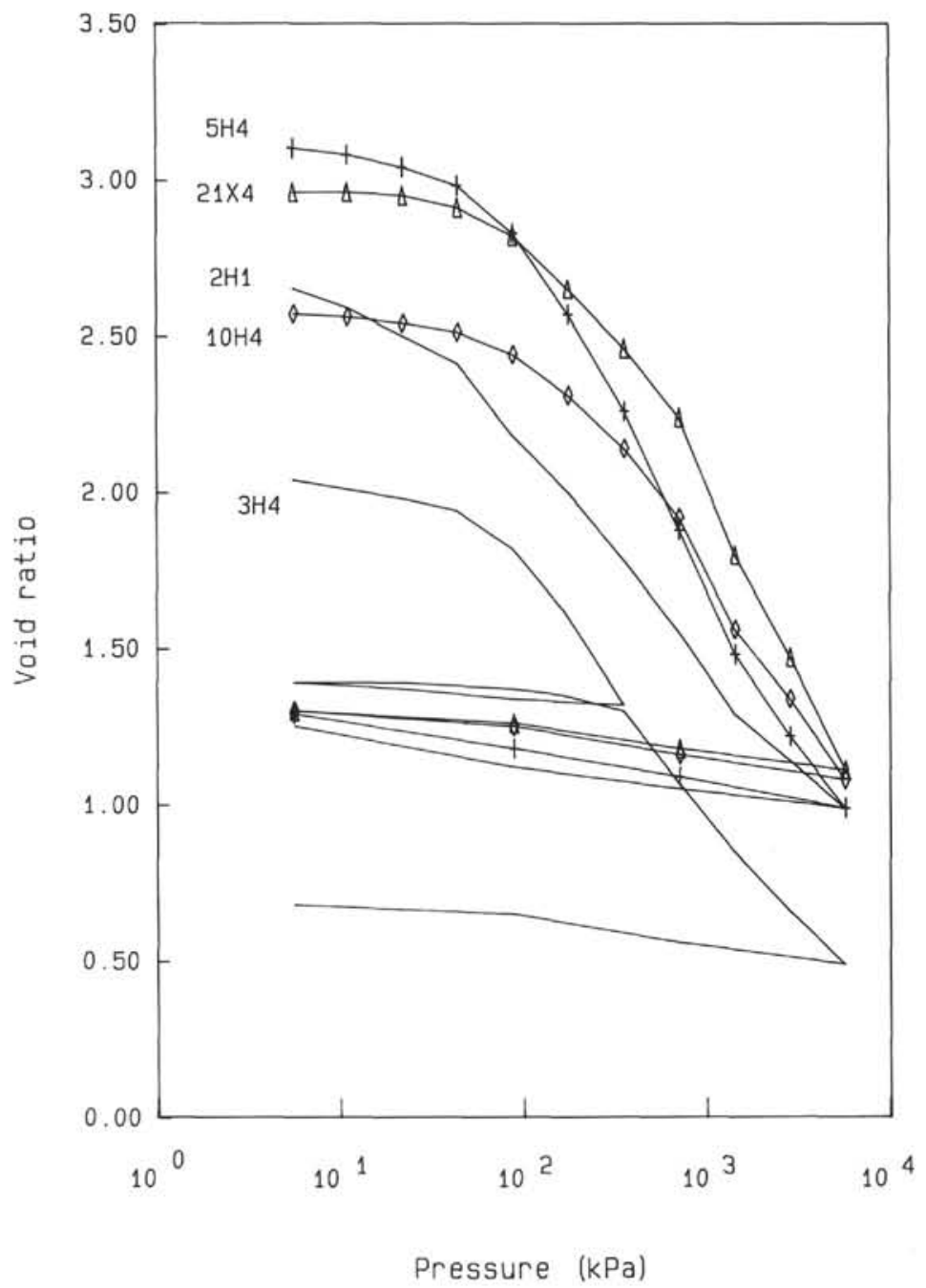

Figure 6. Void ratio vs. logarithm of vertical effective pressure plots of sediments from Site 799

Table 5, Samples 128-798B-16X-6 and 128-798B-25X-3 consist mainly of silt-sized material, whereas the sand content is less than $2 \%$ and the clay fraction is in the range between about 20\% (798B-16X-6) and 39\% (798B-25X-3). According to Bryant et al. (1981), an increase of the clay-size fraction should reduce permeability, and an increasing sand content should enlarge permeability. This relationship is obviously valid for Sample 128-798B-9H-3, where an increase in the sand fraction to values of $>4 \%$ lead to a higher permeability.

The depth intervals from where Samples 128-798B-16X-6 and 128798b-25X-3 were taken (Table 4) are characterized by a high amount of biogenic silica, mainly diatom tests (see "Lithostratigraphy" section, Shipboard Scientific Party, 1990b). Sediments rich in biogenic silica (like diatomaceous and radiolarian ooze) are generally characterized by a small decrease of porosity with increasing pressure (Hamilton, 1976; Bryant et al., 1981; Einsele, 1982; Bayer and Wetzel, 1989; Holler, 1989; Nobes et al., this volume; Pittenger et al., 1989). This results from high pore space of the diatom and radiolarian frustules. The high permeabilities observed in Samples 128-798B-16X-6 and -798B-25X-3 are the result of the interconnection of the pore space within the sediments rich in biogenic silica. This open structure allows a much better flow of fluids through these sediments, compared to the more terrigenous-influenced sediment sections of Site 798.

Figure 9 shows the permeabilities calculated at the estimated overburden pressure for Site 799 vs. depth below seafloor. A permeability of $1.56 \times 10^{-6} \mathrm{~cm} / \mathrm{s}$ was determined for the near mud-line sample ( $2.55 \mathrm{mbsf}$, see Table 4). Permeability decreases to $9.87 \times 10^{-8}$ $\mathrm{cm} / \mathrm{s}$ at a depth of $16 \mathrm{mbsf}$ (Sample 128-799A-3H-4). The remaining samples show a steady decrease of permeability to a value of $2.23 \times$ $10^{-8} \mathrm{~cm} / \mathrm{s}$ at a depth of about 190 mbsf (Table 4).

A comparison of permeabilities at the overburden pressure and at the pressure level 0-5.6 $\mathrm{kPa}$ reveals that for Site 799 the influence of overburden pressure masks the effects of differences in texture and lithology. Sample 128-799A-21X-4 may serve as a good example for this. Although this sample is characterized by a sand content of $>5 \%$ (Table 5) and shows a high amount of biogenic silica (see "Lithostratigraphy" section, Shipboard Scientific Party, 1990c), permeability is roughly two times smaller, compared to the permeability of Sample 128-799A-10H-4 (Table 4). The permeability of Sample 128-799A-21X4 at the pressure level $0-5.6 \mathrm{kPa}$ shows a value of $7.14 \times 10^{-7} \mathrm{~cm} / \mathrm{s}$, compared to $5.04 \times 10^{-7} \mathrm{~cm} / \mathrm{s}$ for Sample 128-799A-10H-4, 135-145 $\mathrm{cm}$. At this lower pressure, there is little difference in permeability.

Figure 10 shows permeability as a function of porosity of selected samples from Sites 798 and 799. In order to show the relationship between permeability and porosity for the different lithologies recovered in the upper parts of the sites, the results from samples dominated by terrigenous material (e.g., 128-798B-1H-1, 128-799A-3H-4) and from a sample dominated by biogenic silica $(128-799 \mathrm{~A}-21 \mathrm{X}-4,140-150 \mathrm{~cm})$ were used. All samples show a very rapid decrease of permeability with decreasing porosity. Similar results were reported by Bryant et al. (1986) for sediments from the Mississippi Fan. A linear regression using the highest and 
Table 3. Consolidation characteristics and excess pore-water pressures for Site 799.

\begin{tabular}{|c|c|c|c|c|c|c|c|}
\hline \multirow{2}{*}{$\begin{array}{l}\text { Core. section. } \\
\text { interval }(\mathrm{cm})\end{array}$} & \multirow{2}{*}{$\begin{array}{l}\text { Overburden } \\
\text { pressure } \\
\text { (kPa) }\end{array}$} & \multicolumn{2}{|c|}{$\begin{array}{l}\text { Preconsolidation } \\
\text { pressure } \\
\text { (kPa) }\end{array}$} & \multicolumn{2}{|c|}{$\begin{array}{l}\text { Excess pore-water } \\
\text { pressure } \\
\text { (kPa) }\end{array}$} & \multicolumn{2}{|c|}{ OCR } \\
\hline & & min. & max. & $\min$. & $\max$. & $\min$. & $\max$. \\
\hline \multicolumn{8}{|l|}{ Hole $799 \mathrm{~A}$} \\
\hline $2 \mathrm{H}-1.135-145$ & 14.90 & 23,0 & 33.5 & 0.0 & 0.0 & 1.5 & 2.3 \\
\hline $3 \mathrm{H}-4.140-150$ & 78.40 & 35.5 & 70.0 & 8.4 & 42.9 & 0.5 & 0.9 \\
\hline $5 \mathrm{H}-4,135-145$ & 177.10 & 78.0 & 100.0 & 77.1 & 99.1 & 0.4 & 0.6 \\
\hline $10 \mathrm{H}-4.135-145$ & 454.00 & 120.3 & 162.2 & 291.8 & 333.7 & 0.3 & 0.4 \\
\hline $21 X-4.130-140$ & 1000.86 & 178.0 & 263.0 & 737.9 & 822.9 & 0.2 & 0.3 \\
\hline
\end{tabular}

lowest values for each sample yielded that permeability decreases from the sixth to the seventh power of porosity. This in good agreement with correlations between permeability and porosity shown by Bryant et al. (1981). A exponential fit performed on all data for the samples yielded the following functions:

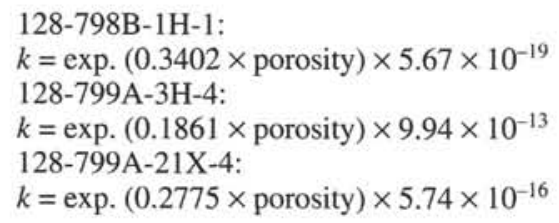

\section{Mechanisms Contributing to Underconsolidation}

Previous sections showed that the sediments of Sites 798 and 799 are mostly underconsolidated. The typical characteristics of underconsolidated sediments are low shear-strength values and high porewater pressures. Sangrey (1977) summarized the mechanisms responsible for underconsolidation. These are as follows:

1. Rapid deposition of sediments.

2. Gas in sediment.

3. Leakage of an artesian water or gas pressure source.

4. Repeated loading of the sediment.

In the following section, these factors are discussed in terms of their contribution to the observed underconsolidation of the sediments from Japan Sea.

\section{Rapid Sedimentation}

Theoretical models of underconsolidation caused by rapid sedimentation were postulated by Terzaghi (1956) and Gibson (1958) and substantiated by field measurements (Fisk and McClelland, 1959; Sangrey et al., 1979). The model of Gibson (1958) was applied to the data from Sites 798 and 799. For Site 798, an average sedimentation rate of $12.5 \mathrm{~cm} / \mathrm{k} . \mathrm{y}$. has been used for the upper $250 \mathrm{mbsf}$. The coefficient of consolidation $\left(c_{v}\right)$ from the laboratory consolidation tests ranges from $3.40 \times 10^{-3} \mathrm{~cm}^{2} / \mathrm{s}$ to $3.90 \times 10^{-4} \mathrm{~cm}^{2} / \mathrm{s}$. The resulting time factor varies between 0.08 and 0.013 , leading to an average degree of consolidation of 0.9 .

For Site 799, an average sedimentation rate of $8 \mathrm{~cm} / \mathrm{k}$.y. was used for the upper $190 \mathrm{mbsf}$. The minimum and maximum values of the coefficient of consolidation were $2.73 \times 10^{-4} \mathrm{~cm}^{2} / \mathrm{s}$ and $2.19 \times 10^{-3} \mathrm{~cm}^{2} / \mathrm{s}$, respectively. These values result in an average degree of consolidation of higher than 0.9. From this exercise it can be concluded that the sedimentation rate is not high enough to explain the degree of underconsolidation determined from the laboratory consolidation tests.

\section{Gas in Sediment}

The generation of gas within the sediments by geochemical and bacteriological processes depends on factors such as the amount of
Pressure (KPa)

$0 \quad 10020030040050060070080090010001100$

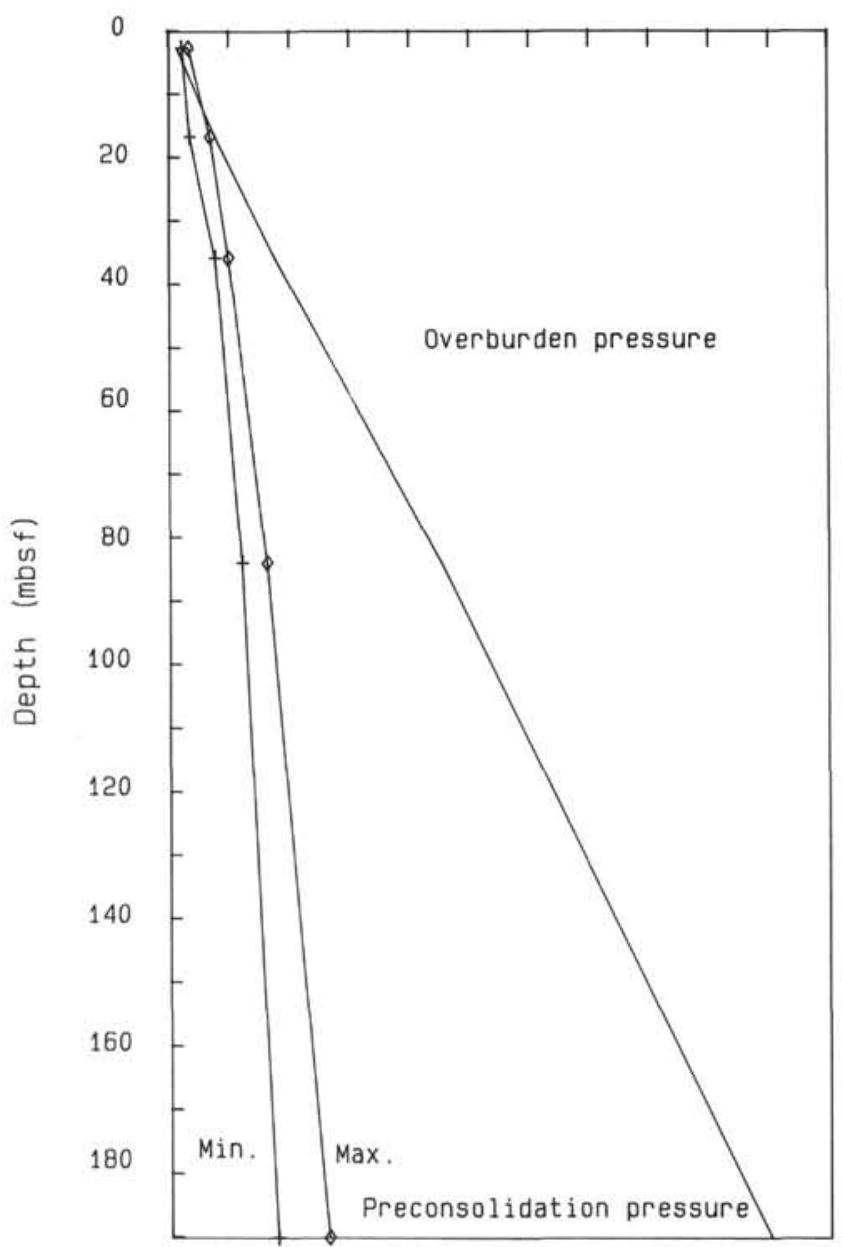

Figure 7. Plot of sedimentary overburden pressure assuming hydrostatic conditions as a function of sub-bottom depth at Site 799. The minimum and maximum preconsolidation pressure as determined from laboratory consolidation tests at Site 799 are also included. This plot shows that the excess pore-water pressure increases with increasing depth below the seafloor.

organic material, sedimentation rate, and heat flow (Demaison and Moore, 1980).

Sangrey (1977) pointed out that biogenic gas is normally dissolved in pore water. As more gas is produced, the gas saturation limit of the pore water will be reached at a given pore water pressure, and free gas will form bubbles. The gas in bubble form increases the porewater pressure, leading to underconsolidation of the sediment.

The sediments recovered from Sites 798 and 799 are characterized by methane concentrations varying between 14 and $155,000 \mathrm{ppm}$ (Shipboard Scientific Party, 1990b, 1990c). Gas in sediments is apparently the major mechanism contributing to underconsolidation of sediments from the Japan Sea.

\section{Leakage From an Artesian Water or Gas Pressure Source}

Pressure migration from a deep source of gas may also increase the pore water pressure and contribute to underconsolidation of sediments. Drilling had to be stopped early at both sites during Leg 128 because of hydrocarbon composition indicating possible thermogenic gas (see "Organic Geochemistry," sections in Shipboard Scientific Party, 1990b, 1990c). At Site 798, the lowermost cores still contained immature organic 
matter that has not reached the stage of gas generation. One must therefore conclude that the hydrocarbons observed most likely migrated from other source rocks (Shipboard Scientific Party, 1990b). The amount of underconsolidation resulting from gas migration cannot be quantified, because this would require knowledge about permeability of the whole sediment section that was cored and the net pressure of the source.

\section{Repeated Loading of Sediments}

Repeated loading of the sediment due to wave action can be excluded as a mechanism contributing to underconsolidation because the water depth at both sites (Site 798: $903 \mathrm{~m}$; Site 799: $2084 \mathrm{~m}$ ) is well beyond the limit of effective wave loading of about $150 \mathrm{~m}$ (Watkins and Kraft, 1978).

Repeated loading of the sediments by earthquake shocks would increase the pore water pressure only for a relative short time. After the earthquake shock, excess pore-water pressure would dissipate quickly; however, repeated loading by earthquake shocks may contribute to the state of underconsolidation. The increase of underconsolidation with increasing depth can not be explained by this mechanism.

\section{SUMMARY}

The state of consolidation of Japan Sea sediments, determined by means of laboratory consolidation tests, agrees well with the consolidation characteristics inferred from the undrained shear strength/sedimentary overburden pressure-ratios.

In general, sediments from the Japan Sea are overconsolidated to normally consolidated in the upper $20 \mathrm{mbsf}$. Below the zone of over- to normal consolidation, the sediments are generally underconsolidated. The degree of underconsolidation increases with increasing depth below seafloor. These results are in good agreement with previous determinations of consolidation characteristics of sediments from the Japan Sea (Trabant et al., 1975). The most probable mechanism responsible for the generation of a high excess pore-water pressure, leading to the observed degree of underconsolidation, is gas in sediments.

Permeability determinations show that sediment texture and lithologic changes greatly influence permeability, but that consolidation is the determining factor for these sediments.

\section{ACKNOWLEDGMENTS}

Support was provided by the German Science Foundation (Deutsche Forschungsgemeinschaft). P. Offermann (Kiel) performed determinations of the Atterberg limits and grain size analyses. I thank $\mathrm{H}$. Klinge and the CT team of the Neurochirurgische Universitätsklinik (Kiel) for running the CT scanner. W. Rehder (Kiel) provided technical help. I thank Elliott Taylor and an anonymous reviewer for careful and detailed comments.

\section{REFERENCES}

Bayer, U., and Wetzel, A., 1989. Compactional behavior of fine-grained sedimentsexamples from Deep sea Drilling Project cores. Geol. Rundsch., 78:807-819.

Bouma, A. H., 1969. Methods for the Study of Sedimentary Structures: New York (Wiley).

Bryant, W. R., and Bennett, R. H., 1988. Origin, physical properties, and mineralogical nature of Red Clays: the Pacific Ocean Basin as a model. Geo-Mar. Lett., 8:189-9.

Bryant, W. R., Bennett, R., and Katherman, C., 1981. Shear strength, consolidation, porosity, and permeability of oceanic sediments. In Emiliani, C. (Ed), The Sea (Vol.7): The Oceanic Lithosphere: New York (Wiley), 1555-1616.

Bryant, W. R., Wetzel, A., Taylor, E., and Sweet, W., 1986. Consolidation characteristics and permeability of Mississippi Fan sediments. In Bouma, A. H., Coleman, J. M., Meyer, A. W., et al., Init. Repts. DSDP, 96: Washington (U.S. Govt. Printing Office), 797-809.

Casagrande, A., 1932. Research on the Atterberg limits of soils. Public Roads, $13: 121-130$

Demaison, G. J., and Moore, G. T., 1980. Anoxic environments and oil source bed genesis. Org. Geochem., 2:9-31.
Dunlap, W. A., Bryant, W. R., Bennett, R., and Richards, A. F., 1978. Pore pressure measurements in underconsolidated sediments. Proc. 10th Offshore Tech. Conf., Pap. No. 3168:1049-1058.

Dunlap, W. A., Bryant, W. R., Williams, G. N., and Suhayda, J. N., 1979. Storm wave effects on deltaic sediments - results of SEASWAB I and II. Proc. Conf. Port and Ocean Engineering Under Arctic Conditions. Trondheim, Norway.

Einsele, G., 1982. Mass physical properties of Pliocene to Quaternary sediments in the Gulf of California, Deep Sea Drilling Project Leg 64. In Curray, J. R., Moore, D. G., et al., Init. Repts. DSDP, 64: Washington (U.S. Govt. Printing Office), 529-542.

Fisk, H. W., and McClelland, B., 1959. Geology of continental shelf off Louisiana: its influence on offshore foundation design. Geol. Soc. Am. Bull., 70:1369-1394.

Gibson, R. E., 1958. The process of consolidation in a clay layer increasing in thickness with time. Geotechnique, 8:171-182.

Hamilton, E. L., 1976. Variations of density and porosity with depth in deep-sea sediments. J. Sediment. Petrol., 46:280-300.

Holler, P., 1988. Sedimentäre Rutschmassen in der Tiefsee. Ber-Rep. Geol. Paläontol. Inst. Univ. Kiel, 23:1-141.

, 1989. Mass physical properties of sediments from Bransfield-Strait and northern Weddell Sea. Mar. Geotechnol., 8:1-18.

Holler, P., and Kögler, F.-C., 1990. Computer Tomography: A nondestructive, high-resolution technique for investigation of sedimentary structures. Mar Geol., 91:263-266.

Lambe, T. W., 1951. Soil Testing for Engineers: New York (Wiley).

Marine Geotechnical Consortium, 1985. Geotechnical properties of Northwest Pacific pelagic clays, Deep Sea Drilling Project Leg 86, Hole 576A. In Heath, G. R., Burckle, L. H., et al., Init. Repts. DSDP, 86: Washington (U.S. Govt. Printing Office), 723-758.

Matthews, W. H., and Boyer, R. E. (Eds.), 1976. Dictionary of Geological Terms (Rev. ed.): New York (Anchor Press).

Pittenger, A., Taylor, E., Bryant, W., 1989. The influence of biogenic silica on the geotechnical stratigraphy of the Voring Plateau: Norwegian Sea. In Eldholm, O., Thiede, J., et al., Proc. ODP, Sci. Results., 104: College Station, TX (Ocean Drilling Program), 923-940.

Richards, A. F., 1962. Investigation of deep sea sediment cores, II: mass physical properties. U.S. Navy Hydrogr. Office Tech. Rep., 106.

Sangrey, D. A., 1977. Marine geotechnology-state of the art. Mar. Geotechnol., 2:45-80.

Sangrey, D. A., Booth, J. S., and Hathaway, J. C., 1979. The Atlantic Margin Coring Project (AMCOR) of the USGS: geotechnical observations. Proc. Conf. Port and Ocean Engineering Under Arctic Conditions. Trondheim, Norway.

Schultheiss, P. J., and McPhail, S. D., 1986. Direct indication of pore-water advection from pore pressure measurements in Madeira Abyssal Plain sediments. Nature, 320:348-350.

Shipboard Scientific Party, 1990a. Explanatory notes. In Ingle, J. C., Jr., Suyehiro, K., von Breymann, M. T., et al., Proc. ODP, Init. Repts., 128: College Station, TX (Ocean Drilling Program), 39-64.

, 1990b. Site 798. In Ingle, J. C., Jr., Suyehiro, K., von Breymann, M. T., et al., Proc. ODP, Init. Repts., 128: College Station, TX (Ocean Drilling Program), 121-236.

, 1990c. Site 799. In Ingle, J. C., Jr., Suyehiro, K., von Breymann, M. T., et al., Proc. ODP, Init. Repts., 128: College Station, TX (Ocean Drilling Program), 237-402.

Skempton, A. W., 1970. The consolidation of clay by gravitational compaction. Quat. J. Geol. Soc. London, 125:373-412.

Taylor, D. W., 1948. Fundamentals of Soil Mechanics: New York (Wiley).

Terzaghi, K., 1943. Theoretical Soil Mechanics: New York (Wiley).

, 1956. Varieties of submarine slope failures. Proc. 8th Texas Soil Mech. Eng. Conf., 1-41.

Trabant, P. K., Bryant, W. R., and Bouma, A. H., 1975. Consolidation characteristics of sediments from Leg 31 of the Deep Sea Drilling Project. In Karig, D. E., Ingle, J. C., et al., Init. Repts. DSDP, 31: Washington (U.S. Govt. Printing Office), 569-572.

Watkins, D. J., and Kraft, L. M., 1978. Stability of continental shelf and slope of Louisiana and Texas. In Bouma, A. H., Moore, G. T., and Coleman, J. M. (Eds.), Framework, Facies, and Oil Trapping Characteristics of the Upper Continental Margin. AAPG Stud. Geol., 7:267-286.

Date of initial receipt: 1 March 1991

Date of acceptance: 17 October 1991

Ms 127/128B-232 
Coefficient of permeability

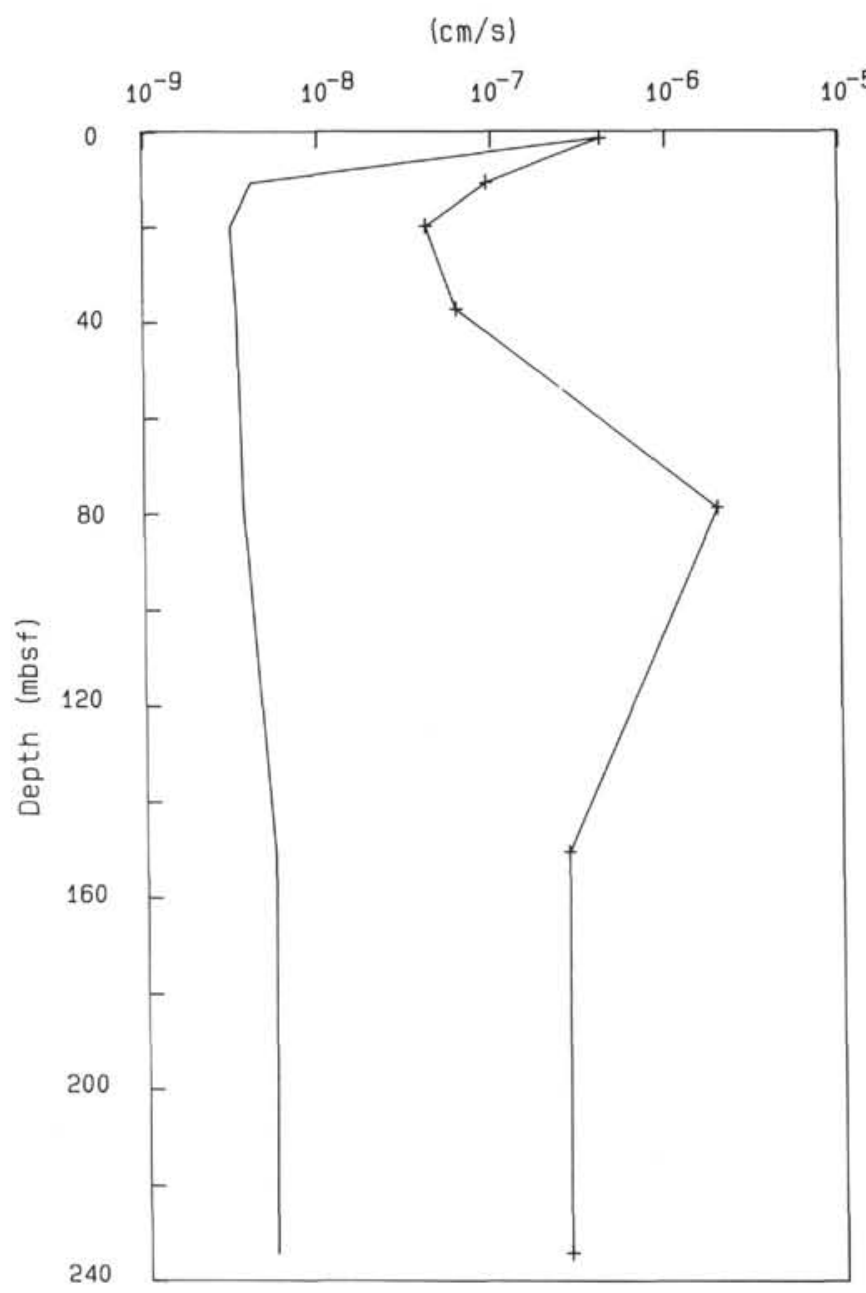

Figure 8. Permeability of Site 798 sediments as a function of depth below the seafloor. Left line shows permeability at the sedimentary overburden pressure, assumed to represent in-situ conditions. The right line represents permeability calculated for the $0.0-5.6 \mathrm{kPa}$ level from laboratory consolidation tests.
Coefficient of permeability

$(\mathrm{cm} / \mathrm{s})$

$\begin{array}{llll}10^{-9} & 10^{-8} & 10^{-7} & 10^{-6}\end{array}$

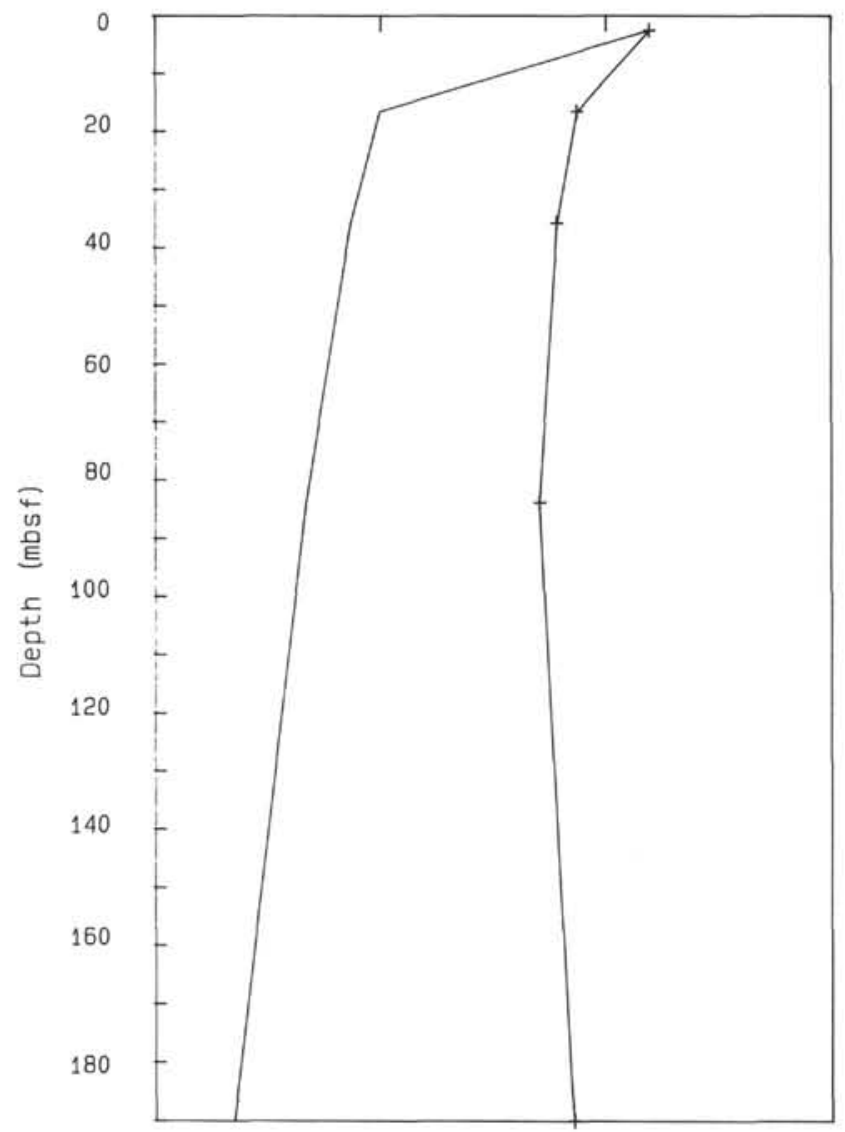

Figure 9. Permeability of Site 799 sediments as a function of depth below the seafloor. Left line shows permeability at the sedimentary overburden pressure, assumed to represent in-situ conditions. The right line represents permeability calculated for the $0.0-5.6 \mathrm{kPa}$ level from laboratory consolidation tests. 
Table 4. Permeabilities for Sites 798 and 799.

\begin{tabular}{|c|c|c|c|c|}
\hline \multirow[b]{2}{*}{$\begin{array}{l}\text { Core, section, } \\
\text { interval }(\mathrm{cm})\end{array}$} & \multicolumn{4}{|c|}{ Permeability $\left(\mathrm{cm} / \mathrm{s} \times 10^{-7}\right)$} \\
\hline & direct & $\begin{array}{l}\text { indirect } \\
(0-5.6 \mathrm{k}\end{array}$ & $\begin{array}{l}\text { at overburden } \\
\mathrm{Pa} \text { ) }\end{array}$ & $\begin{array}{l}\text { direct/indirect } \\
\text { pressure }\end{array}$ \\
\hline \multicolumn{5}{|l|}{ Hole 798B } \\
\hline $1 \mathrm{H}-1,135-150$ & 62.10 & 43.00 & 43.00 & 1.44 \\
\hline $2 \mathrm{H}-1,140-150$ & 9.36 & 9.55 & 0.42 & 0.98 \\
\hline $3 \mathrm{H}-1,140-150$ & 4.83 & 42.50 & 0.32 & 0.11 \\
\hline $4 \mathrm{H}-7,84-94$ & 4.93 & 6.35 & 0.35 & 0.77 \\
\hline $9 \mathrm{H}-3,140-150$ & 58.50 & 197.00 & 0.37 & 0.30 \\
\hline $16 \mathrm{X}-6,140-150$ & 34.30 & 26.60 & 0.55 & 1.29 \\
\hline $25 X-3,140-150$ & 155.0 & 26.00 & 0.54 & 6.08 \\
\hline \multicolumn{5}{|l|}{ Hole 799A } \\
\hline $2 \mathrm{H}-1,135-145$ & 11.40 & 15.60 & 15.60 & 0.73 \\
\hline $3 \mathrm{H}-4,140-150$ & 9.36 & 7.39 & 0.99 & 1.27 \\
\hline $5 \mathrm{H}-4,135-145$ & 9.55 & 6.04 & 0.74 & 1.58 \\
\hline $10 \mathrm{H}-4,135-145$ & 4.83 & 50.40 & 0.47 & 0.10 \\
\hline $21 \times-4,130-140$ & 243.0 & 7.14 & 0.22 & 34.00 \\
\hline
\end{tabular}

Table 5. Sand-silt-clay ratios for Sites 798 and 799.

\begin{tabular}{cccr}
\hline $\begin{array}{c}\text { Core, section, Sand } \\
\text { interval }(\mathrm{cm})\end{array}$ & $\begin{array}{c}\text { Silt } \\
(\%)\end{array}$ & $\begin{array}{l}\text { Clay } \\
(\%)\end{array}$ & $(\%)$ \\
\hline Hole 798B & & & \\
& & & \\
IH-1, 135-150 & 1.60 & 67.00 & 31.40 \\
2H-1, 140-150 & 1.42 & 90.78 & 7.80 \\
3H-1, 140-150 & 0.99 & 84.81 & 14.20 \\
$4 \mathrm{H}-7,84-94$ & 1.83 & 82.37 & 15.80 \\
$9 \mathrm{H}-3,140-150$ & 4.37 & 84.23 & 11.40 \\
16X-6, 140-150 & 1.71 & 78.59 & 19.70 \\
$25 \mathrm{X}-3,140-150$ & 0.08 & 61.05 & 38.87 \\
& & & \\
Hole 799A & & & \\
& & & \\
2H-1, 135-145 & 0.35 & 67.65 & 32.00 \\
$3 \mathrm{H}-4,140-150$ & 4.45 & 63.35 & 32.20 \\
5H-5, 135-145 & 0.03 & 72.87 & 27.10 \\
10H-4, 135-145 & 0.59 & 81.41 & 18.00 \\
$21 \mathrm{X}-4,130-140$ & 5.15 & 73.65 & 21.20 \\
\hline
\end{tabular}

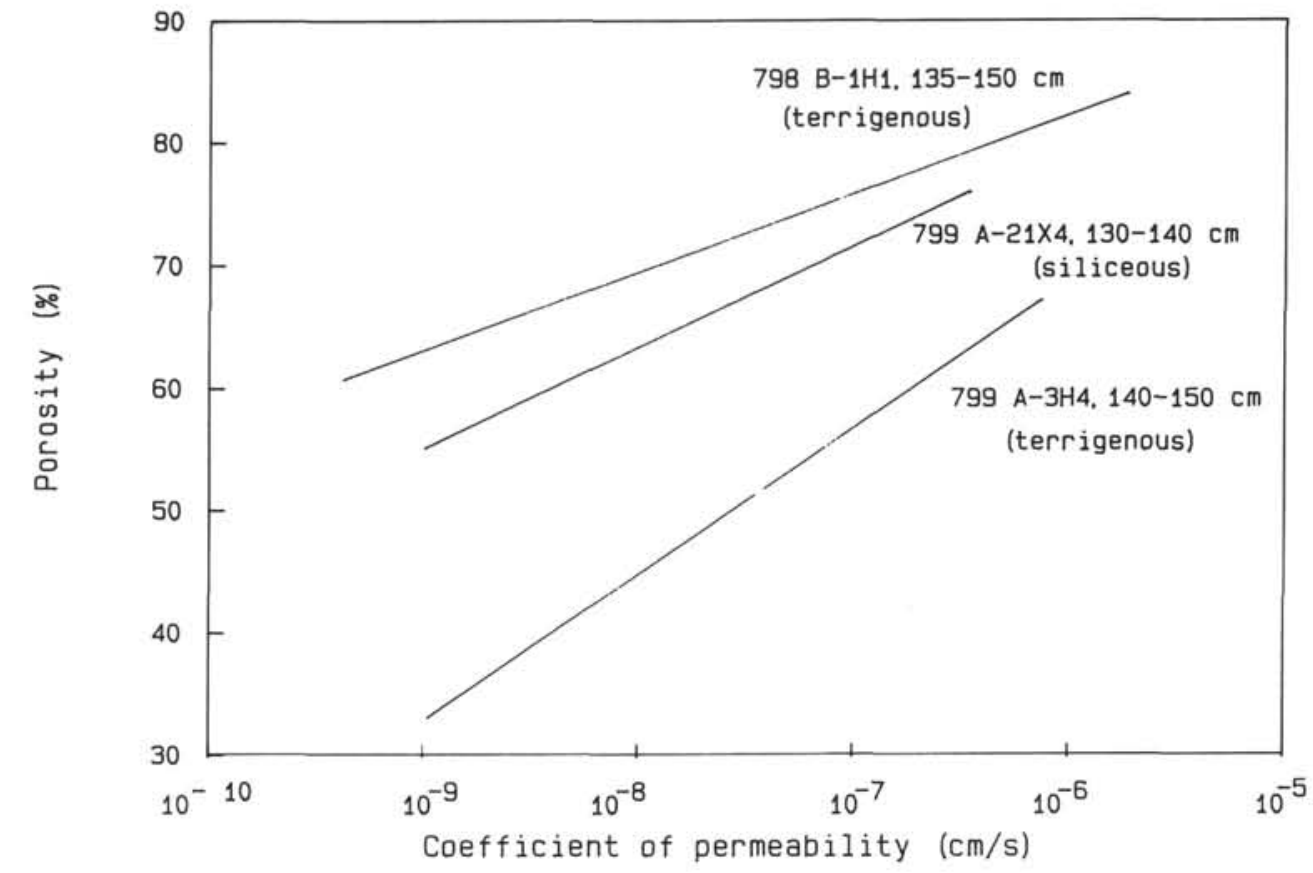

Figure 10. Permeability as a function of porosity of selected samples from Sites 798 and 799. 

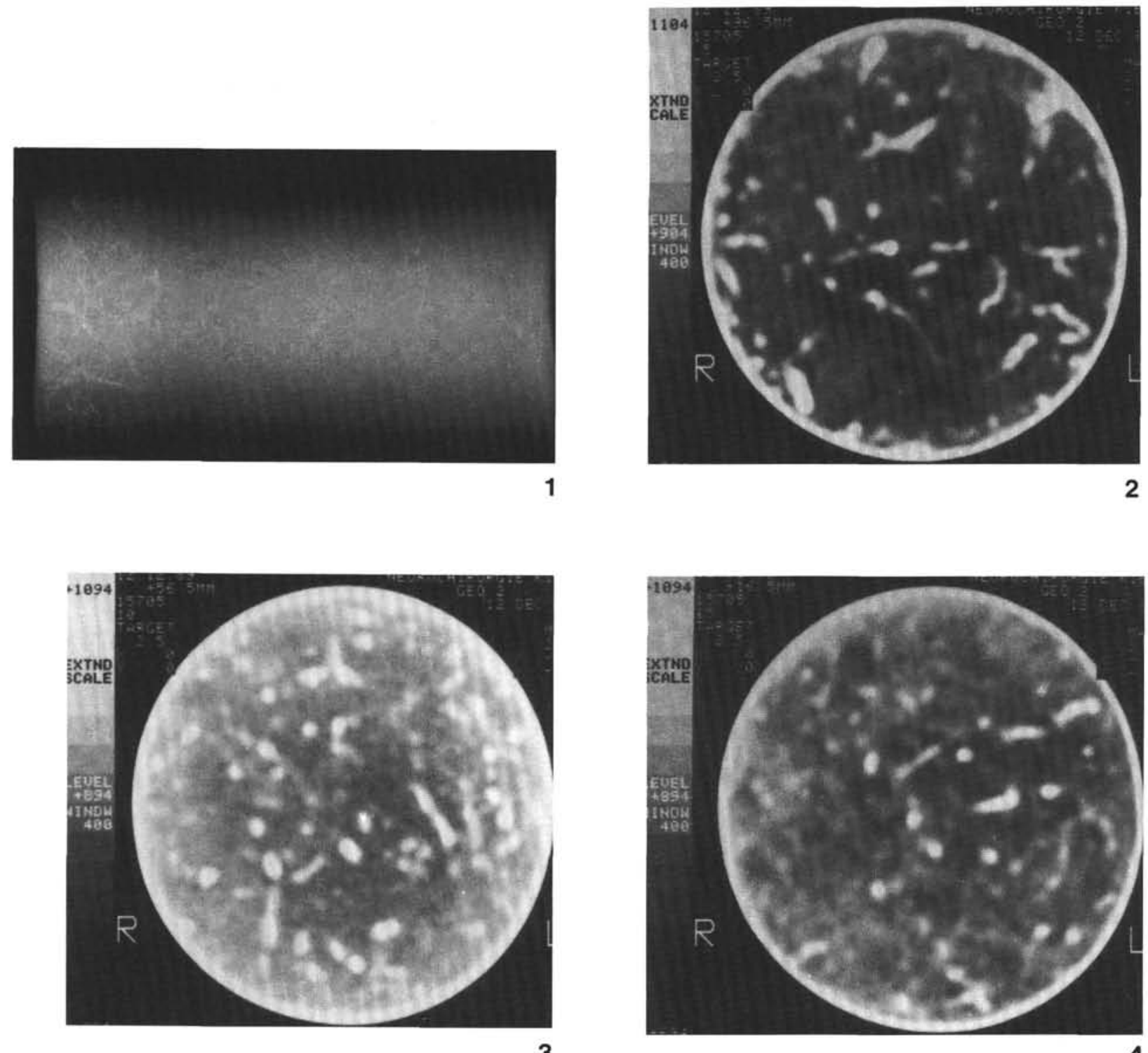

3

Plate 1. Comparison between a conventional X-ray radiograph and computer tomograms of Sample 799A-3H-4, 140-150 cm. 1. Conventional X-ray radiograph of the whole-round sample. 2-4. Tomograms from the upper, central, and lower parts of the sample. Main features are Chondrites-type burrows filled by sulfide and a matrix material of various densities. Note the generally much-higher resolution and contrast of the features portrayed in these tomograms. 